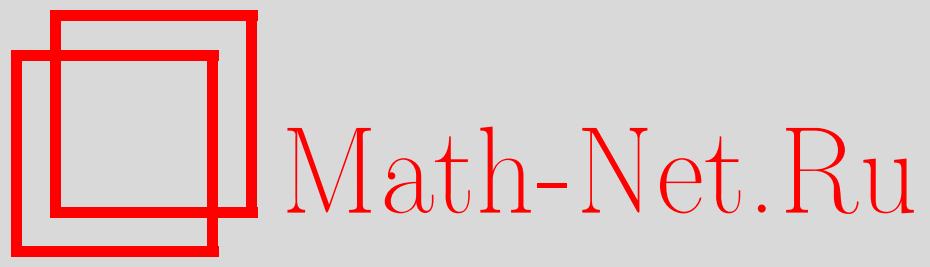

Л. Белопухов, ИТЭР - сегодня, Квант, 2018, номер 10, 2-5

DOI: https://doi.org/10.4213/kvant20181001

Использование Общероссийского математического портала Math-Net.Ru подразумевает, что вы прочитали и согласны с пользовательским соглашением http: //www . mathnet.ru/rus/agreement

Параметры загрузки:

IP: 34.229 .108 .108

26 апреля 2023 г., 13:14:33

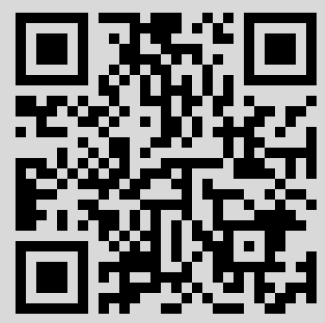




\section{ИТЭР - сегодня}

\section{Л.БЕЛОПУХОВ}

$\mathrm{B}$ СТАТЬЕ «ИТЭР - ЗЕМНАЯ ЗВЕЗДА» («Квант» №8 за 2018 г.) рассказывалось о возникновении идеи и о попытках воплощения ее в жизнь, приведших к созданию гигантского международного проекта ИТЭР. Самая крупная стройка XXI века приобрела уже такую известность, что сочетание букв «ИТЭР» перестали считать аббревиатурой, требующей расшифровки, а понимают как часть латинского iter (путешествие) - путь в энергетическое будущее человечества.

Советом ИТЭР официально заявлено, что пуск реактора состоится в 2025 году. На интернетовском сайте «ИТЭР сегодня» - сотни фотографий этой стройки. Имеются первые фотографии, когда в 2011 году был расчищен от леса и строго выверен по горизонтали целый комплекс огромных полян общим размером в несколько сотен футбольных полей. На сегодняшних снимках - грандиозная панорама самых разнообразных сооружений.

У этой панорамы есть центр - котлован круговой формы, в котором будет находится главное сооружение установки, а

DOI: https://doi.org/10.4213/kvant20181001

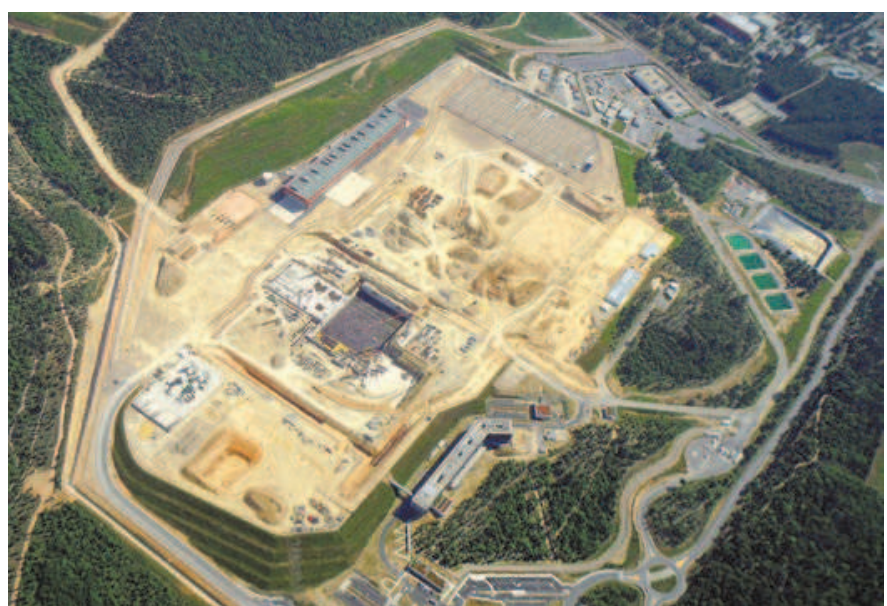

именно цилиндр диаметром 30 м и такой же высотой. Это - криостат, огромный холодильный термос, в оболочке которого будет поддерживаться температура порядка $-200{ }^{\circ} \mathrm{C}(73 \mathrm{~K})$. Хладоагентом будет жидкий азот, циркулирующий по трубчатым экранам, размещенным в оболочке криостата. Оболочку будут пронизывать сотни отверстий для трубопроводов ввода и вывода жидкого азота и электрических кабелей.

Внутри криостата - сердце реактора, вакуумная камера, давшая название всему устройству токамак. По форме она действительно представляет собою несколько искаженный тороид (тор), стоящий на поддоне и прикрытый сверху крышкой. Если строгий тороид напоминает собой баранку, то вакуумная камера реактора больше похожа на гигантский бублик или пончик, в котором периферия толще пустой центральной части. Кстати сказать, на английском научном сленге токамак так и называется doughnut - «пончик». Наружный диаметр этого пончика 19 м, внутренний 6 м, высота 11 м, общая масса 5000 т. Стенки вакуумной камеры выполнены из меди, упрочненной стальными деталями (делать их целиком из стали нельзя, ведь сквозь стенки камеры должны проникать внутрь магнитные поля, рождаемые магнитами, сердечники и обмотки которых расположены внутри криостата вокруг камеры). Особенно впечатляют тороидальные магниты, окружающие камеру, - как 18 лепестков еще нераспустившегося бутона. Магнитные поля проникают внутрь камеры сквозь медные «окна» и создают условия для сжатия и равновесия 
плазменного шнура, в котором и происходит термоядерная реакция.

В вакуумной камере (и внутри криостата) давление не должно превышать $10^{-4}$ Па, что в миллиард раз меньше атмосферного давления. Для создания такого вакуума в огромном объеме криостата и вакуумной камеры 400 насосов разного типа должны работать не меньше двух недель.

Стенки вакуумной камеры - двойные. Как и стенки криостата, они представляют собой охладительный термос, в котором хладоагентом будет дистиллированная вода под давлением 4 МПа. Поступая с температурой $70^{\circ} \mathrm{C}$, вода с большой скоростью будет проходить сквозь стенки вакуумной камеры, нагреваясь до $120^{\circ} \mathrm{C}$ и унося с собою основную часть энергии, выделяющейся в термоядерной реакции. При этом вода, покидая стенки камеры, еще только начинает закипать и шумит точь-в-точь, как начинающий закипать чайник. Этот шум будет тщательно контролироваться акустическими приборами - как показатель нормальной работы реактора. Активное кипение начинается, когда вода покидает камеру и ее давление начинает падать.

В токамаке не предусмотрено использование водяного пара для вращения турбин турбогенератора и получения электрического тока. Это не промышленный, а экспериментальный реактор. Он предназначен для отработки всех отдельных элементов термоядерного устройства. Поэтому пароводяная смесь после охлаждения, очистки и проверки на чистоту вновь будет поступать туда, где она отбирает тепловую энергию, - в «термосное» пространство стенок вакуумной камеры. В этом есть некоторое сходство с первыми атомными (плутониевыми) реакторами (1942 г., Чикаго, Э.Ферми; 1946 г., Москва, И.В.Курчатов).

Внутренние стенки вакуумной камеры, обращенные к плазменному шнуру, выложены 440 съемными бланкетами (одеялами). Каждая бланкета представляет собой сложную конструкцию из стали и меди с экраном площадью $1,5 \mathrm{~m}^{2}$ и толщиной
10 мм, выполненным из бериллия - тугоплавкого и прочного металла, не взаимодействующего с нейтронами, а отражающего и замедляющего их.

Это и есть главные объекты токамака, принимающие на себя основную энергию термоядерной реакции - кинетическую энергию рождающихся нейтронов, имеющих огромные скорости порядка 20000 км/с. В результате многочисленных последовательных столкновений нейтроны передают свою энергию ядрам бериллия и замедляются. Бланкета нагревается, но не очень сильно (до $240{ }^{\circ} \mathrm{C}$ ). Дальнейшему разогреву препятствует непрерывное омывание внутренней полости камеры водой, которая, нагреваясь, и уносит энергию реакции.

Тепловое излучение плазменного шнура, имеющего температуру 150 миллионов градусов, тоже дает немалый вклад в разогрев воды. Оставшаяся непоглощенной часть излучения проходит во внутреннее помещение к стенкам криостата и отдает свою энергию холодному жидкому азоту. Остается еще «хвостик» излучения - гамма-кванты. Для их поглощения криостат снаружи и сверху окружен мощной бетонной защитой толщиной от 1,5 до 3 метров.

Стоя за этой бетонной стеной, трудно будет представить, что внутри бушует термоядерный звездный жар. А там внутри «стакан» криостата, окруженный разными трубами и механизмами. А внутри криостата - камера-бублик размером с трехэтажный дом, окруженная гигантскими магнитами. И если бы можно было заглянуть внутрь этого бублика, то там обнаружилось бы висящее в вакууме нестерпимо яркое кольцо водородной плазмы - источник термоядерной энергии. Как в сказке - сундук, внутри - шкатулка, в шкатулке - яичко, в нем - золотой перстенек. Или, если угодно, - матрешки, каждая из которых, правда, не копирует предыдущую.

Ну, а что же строится вокруг центрального «сундука»? На снимках видны котлованы, фундаменты, стены многих сооружений и всюду - подъемные краны. А вокруг - складские помещения. Особенно 
впечатляет огромное сооружение рядом с центром. Но это - всего лишь сборный цех, в котором сооружаются отдельные громоздкие детали криостата: поддон, крышка и стены холодильного «термоса». Оказывается, осуществлять надежную сварку этих деталей, состоящих из десятков отдельных стальных листов, можно только в их горизонтальном положении с тщательно проверяемым каждым сварным швом. После сварки гигантский кран будет перемещать эти детали на их постоянное место.

В этом году полностью подготовлено железобетонное основание для поддона криостата, который уже готов в соседнем здании и ждет установки на свое место. Подготовка железобетонного основания и всего фундамента под реактор - чрезвычайно ответственная операция. Ведь многотысячетонные криостат и вакуумная камера не должны испытывать ни малейших деформаций. Все возможные природные колебания грунта должны поглощаться и гаситься фундаментом и основанием.

Между поддоном криостата и его железобетонным основанием должно быть пространство для установки различных технологических устройств. Поэтому фундамент под криостатом имеет очень сложную форму, напоминающую корону. Строители так его и прозвали. Этим летом в ИТЭР-прессе было заявлено об окончании сооружения «короны». Она выполнена из совершенно необычного бетона. Его плотность в полтора раза больше, чем у обыкновенного строительного бетона. Впервые употребленный для него тяжелый гравий был доставлен из Лапландии.

Очень непроста проблема питания плазменного шнура топливом - смесью дейтерия и трития. ИТЭР, как и все предыдущие токамаки, - генератор энергии импульсного действия. Каждый импульс длится около 8 минут. За это время «сгорает» один грамм «топлива», такова масса плазменного шнура. А по выделяющейся энергии этот грамм эквивалентен 10 тоннам каменного угля. К концу импульсного периода температура в шнуре начинает падать - необходима подпитка.

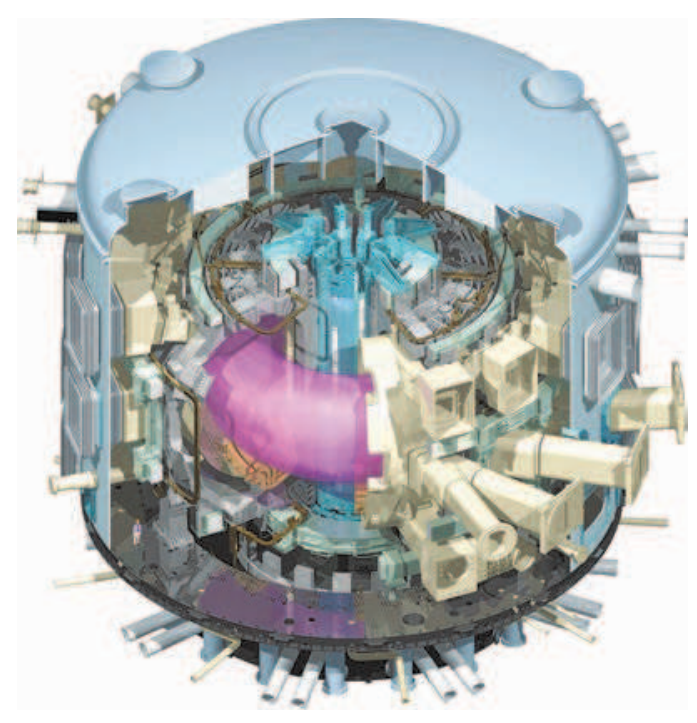

Но при этом нельзя нарушать вакуум во всем криостате. Очередная порция топлива в виде «ледяных» шариков, имеющих температуру 10 К, выстреливается в вакуумную камеру. Одновременно с шариками в камеру вводится импульс высокочастотного электромагнитного поля, рождаемого специальными устройствами - электронно-циклотронными резонаторами (гиротронами). Поле частотой 50 МГц вводится в камеру через 60 окон, выполненных из поликристаллического искусственного алмаза (он прозрачен для такой частоты).

Поглощая энергию поля, шарики топлива ускоряются, ионизуются и затем под действием магнитного поля попадают в плазменный шнур, разогревая его до температуры начала термоядерной реакции. Вновь в шнуре 150 миллионов градусов и 46 тысяч ампер. Вновь нагреваются до кипения потоки воды внутри «лепестков» вакуумной камеры. И так повторяется сотни и тысячи раз, пока не придет пора заменять бериллиевые экраны в бланкетах, передающих энергию нейтронов воде и жидкому азоту, охлаждающему криостат.

Нельзя не остановиться на задаче создания в камере магнитных полей в десятки тесла. Для таких полей ток в обмотках магнитов должен быть не менее 60000 ампер. Это могут быть только сверхпроводящие обмотки. Используются сплавы ниобий-олово и ниобий-тантал, имеющие 
нулевое сопротивление при температуре 3 К. Жгуты проводов называются стрен- $^{-}$ дами. В один жгут в стренде скручиваются 5000 тончайших проволочек сплава (толщина каждой проволочки 6 микрометров), а 1440 стрендов скручиваются в кабель и помещаются в оболочку, внутри которой будет циркулировать жидкий гелий.

Россия уже произвела и доставила на строительную площадку 120 тонн таких кабелей для полоидальных магнитов. (Магнитное поле называется полоидальным, когда оно направлено вдоль линий, проходящих через полюсы сферической системы координат. Именно такое поле используется в токамаке для удержания плазмы в стабильном состоянии.) Их производство было организовано с нуля в 2010 году на Чепецком механическом заводе (г.Глазов, Удмуртия). В работе были задействованы и другие производства и научноисследовательские институты, где разрабатывалось и создавалось необходимое оборудование. Совет ИТЭР высоко оценил этот вклад России в общее дело.

Для обеспечения непрерывного тока жидкого гелия и жидкого азота строится отдельное здание - «фабрика холода», где будут работать самые современные холодильные турбодетандеры и другие установки.

Очень важной задачей является выведение из вакуумной камеры главного продукта реакции - гелия. В нижней части камеры предусматриваются специальные устройства - диверторы (пепельницы). Часть диверторов занимают «кокосы». Так конструкторы ИТЭР прозвали слои активированного угля для поглощения ионов гелия, направляемых туда полоидальным магнитным полем. Дело в том, что наилучшим поглотителем гелия оказался уголь, полученный из сердцевин кокосовых орехов определенного вида. У диверторов есть и другие задачи. В конце каждого цикла нужно вывести из камеры недогоревшее топливо. Дейтерий и тритий разделяются и затем поступают на «фабрику» подготовки топлива.

Но основное количество топлива будет поступать в ИТЭР с заводов по производ- ству дейтерия и трития, находящихся в других местах. Килограмм трития в настоящее время стоит 30 миллионов долларов, а ИТЭР будет расходовать полтора килограмма трития в месяц. Поэтому в проекте следующего реактора ДЕМО предусматривается получение трития непосредственно на реакторе при облучении нейтронами лития.

Задачей дивертора является и сбор бериллиевой пыли, возникающей на бланкетах во время работы реактора. Недопустимо попадание этой пыли в воздух, которым дышат люди. Во всех пунктах сбора бериллиевой пыли и ее эвакуации предусматриваются усиленные меры техники безопасности и тщательный контроль за их соблюдением.

Важнейшей частью проекта становится проектирование и разработка средств контроля и управления всеми технологическими процессами - «фабрики управления». Информация от нескольких сотен датчиков будет преобразовываться в цифровые интерфейсы, поступающие в контроллеры, языком которых будут протоколы, таблицы, диаграммы и т.п. Советом ИТЭР определено, что возглавлять эту работу и создавать большую часть контрольных приборов будут российские ученые и инженеры. Пожалуй, это будет самым существенным вкладом России в создание ИТЭР. В конце 2018 года в Москве состоится IV Международная научно-практическая конференция «Актуальные проблемы информационных технологий, электроники и радиотехники» (ИТЭР-2018), в которой примут участие 26 научных организаций России и Казахстана.

Публикуемая статья - первый опыт популярного описания конструкции ИТЭР и современного состояния его сооружения. Автор старался ограничиваться минимумом сведений, необходимых для понимания сути дела. Но все равно этот минимум получился обширным и содержащим много количественных данных. Удалось ли при этом дать представление о масштабности проекта и его значении - судить читателю. 